\title{
OPTIMALISASI PEMANFAATAN JERAMI PADI SEBAGAI PAKAN DASAR SAPI BALI PENGGEMUKAN MELALUI PERLAKUAN AMONIASI DAN BIOFERMENTASI DENGAN MIKROBA
}

\author{
PARTAMA, I.B.G., I.G.N.G. BIDURA, DAN D.P.M.A. CANDRAWATI \\ Fakultas Peternakan Universitas Udayana \\ e-mail: idabagusgaga@gmail.com
}

\begin{abstract}
ABSTRAK
Penelitian telah dilaksanakan di Gianyar-Bali, untuk mengoptimalkan pemanfaatan jerami padi sebagai pakan dasar sapi bali penggemukan melalui perlakuan amoniasi dan biofermentasi dengan Starbio dan Trichoderma virideae. Rancangan acak kelompok digunakan dalam percobaan ini yang terdiri atas empat perlakuan dan tiga blok sebagai ulangan dengan 1 unit percobaan adalah 1 ekor sapi bali jantan. Perlakuan pertama adalah ransum kontrol yang terdiri atas jerami padi tanpa perlakuan diberikan secara ad libitum + complete feed sebanyak 1.5\% dari bobot hidup sapi. Perlakuan kedua, ketiga, dan keempat adalah sama dengan ransum kontrol tetapi jerami padi diberi perlakuan berturut-turut amoniasi urea, biofermentasi dengan starbio, dan Trichoderma virideae. Peubah yang diamati meliputi konsumsi ransum, deposisi nutrien, retensi energi, pertambahan bobot hidup sapi dan feed conversion ratio (FCR). Hasil penelitian menunjukkan bahwa konsumsi bahan kering ransum kontrol nyata lebih tinggi daripada ransum dengan jerami padi yang diberi perlakuan biofermentasi mikroba. Namun demikian, deposisi nutrien (lemak dan protein), retensi energi dan pertambahan bobot hidup sapi lebih tinggi pada ransum berbasis jerami padi yang diberi perlakuan amoniasi urea dan biofermentasi dengan starbio maupun dengan Trichoderma virideae. Dari keempat perlakuan tersebut, ternyata jerami padi yang diberi perlakuan amoniasi urea memberikan hasil paling baik dengan pertambahan bobot hidup sapi paling tinggi $(0,53$ vs $0,47,0,46$, dan $0,41 \mathrm{~kg} / \mathrm{ekor} / \mathrm{hari}$ ). Berdasarkan hasil penelitian ini dapat disimpulkan bahwa jerami padi dengan amoniasi urea memberikan pemanfaatan secara optimal sebagai pakan dasar sapi bali penggemukan.

Kata kunci: sapi bali, jerami padi, amoniasi, biofermentasi, optimalisasi

\section{OPTIMALIZATION OF THE UTILIZATION OF RICE STRAW AS THE BASIC FEED OF BALI FATTENING CATTLE THROUGH AMMONIATION AND BIOFERMENTATION TREATMENT WITH MICROBA}

\begin{abstract}
A study has been carried out in Gianyar-Bali, to optimize the use of rice straw for fattening Bali cattle feed through ammoniation and biofermentation treatment with Starbio and Trichoderma virideae. The Randomized Block Design used in this experiment consisted of four combinations and three blocks as replications with 1 unit of experiment was 1 Bali bull. The first treatment is to use a ration consisting of rice straw without treatment given ad libitum + complete feed $1.5 \%$ of the live weight of livestock. The second, third, and fourth treatments were the same as ration control, but were also supplemented with urea ammoniation, biofermentation with starbio, and Trichoderma virideae. The measured variables included using the ration, nutrient deposition, energy retention, livestock weight gain and feed conversion ratio (FCR). The results showed that the consumption of dry matter control ration was significantly higher $(\mathrm{P}<0.05)$. However, nutrient deposition, energy retention and weight gain were higher in rice jeram based rations with urea ammonation treatment and biofermentation with starbio or with Trichoderma virideae. Of the four treatments, it turns out that rice straw treated with urea ammonia gave the best results with the highest live weight gain (0.53 vs $0.47,0.46$ and $0.41 \mathrm{~kg} / \mathrm{head} /$ day). Based on the results of this study it can be concluded that rice straw with urea ammoniation provides optimal utilization as the basic feed of Bali fattening cattle.
\end{abstract}

Keywords: bali cattle, rice straw, ammoniation, biofermentation, optimization 


\section{PENDAHULUAN}

Sapi bali merupakan salah ternak unggulan sebagai penghasil daging di Indonesia. Jumlah permintaannya semakin meningkat dari tahun ke tahun. Badan Pusat Statistik (BPS) menyebutkan bahwa kebutuhan daging sapi nasional tahun 2018 sebesar 2,50 kilogram per kapita per tahun dan di tahun 2019 sebesar 2,56 kg per kapita per tahun. Kementerian Pertanian (Kemtan) memproyeksikan produksi daging sapi dalam negeri tahun 2019 sebesar 429.412 ton. Produksi tersebut hanya $62,57 \%$ dari proyeksi kebutuhan daging tahun 2019 yang sebesar 686.270 ton. Maka defisit kebutuhan daging sebesar 256.860 ton akan didatangkan dari impor. Baik itu impor dalam bentuk daging beku, maupun dalam bentuk sapi hidup berupa sapi bakalan. Berdasarkan data tersebut maka sapi Bali sebagai salah satu plasma nutfah Indonesia sangat berpeluang untuk dikembangkan secara maksimal untuk memenuhi kebutuhan daging yang semakin meningkat.

Sapi bali adalah sapi lokal yang diharapkan menjadi hewan unggul dalam menyediakan daging, karena sapi bali memiliki beberapa keunggulan, yaitu sebagai sapi potong, persentase karkasnya tinggi, berkisar antara 54-56\% dan kemampuan adaptasinya sangat baik untuk lingkungan. Sapi bali lebih toleran terhadap pakan berkualitas rendah, dan memiliki efisiensi penggunaan pakan yang lebih baik dibandingkan sapi lokal lainnya dan sapi bali memiliki kualitas genetik yang baik. Menurut Kesuma et al. (2019a), Provinsi Bali dipercaya sebagai satu-satunya wilayah yang memiliki sapi bali murni, sehingga plasma nutfah ini perlu dilindungi oleh kebijakan nasional, sehingga dapat dimanfaatkan dan dilestarikan secara optimal.

Dalam upaya meningkatkan produktivitas ternak sapi, peternak sapi di daerah padat penduduk seperti Bali dihadapkan pada masalah sulitnya penyediaan pakan hijauan baik kuntitas maupun kualitas. Kesulitan dalam penyediaan pakan sangat terasa pada saat musim kemarau. Dilain pihak berlimpahnya limbah pertanian seperti jerami padi yang belum dimanfaatkan secara optimal. Hal ini disebabkan oleh rendahnya kandungan nitrogen, tingginya kandungan serat dan silika.

Jerami padi (Oriza sativa) adalah limbah pertanian yang berpotensi untuk dimanfaatkan sebagai bahan pakan pengganti pakan hijauan. Data Badan Pusat Statistik (BPS) menunjukkan bahwa total produksi padi nasional tahun 2018 berkisar 56,54 juta ton. Sementara itu, produksi padi di Bali pada tahun 2015 sebesar 853.899 ton. Berdasarkan data ini dapat diprediksi produksi jerami padi nasional pada tahun 2018 sebesar 84,81 juta ton, sedangkan produksi jerami padi di Bali tahun 2015 sebesar 1,28 juta ton. Berhubung kualitas jerami padi adalah rendah sebagai bahan pakan maka perlu dilakukan pengolahan untuk meningkatkan kualitasnya.

Pemanfaatan jerami padi sebagai pakan sapi dapat ditingkatkan melalui penerapan teknologi, yaitu secara kimia (perlakuan alkali dan amoniasi), biologis (biofermentasi dengan mikroba) dan perlakuan fisik (pembuatan pellet dan pemanasan pada tekanan tinggi). Perlakuan biologis seperti penambahan probiotik (ragi tape) pada ransum berbahan utama jerami padi dapat meningkatkan kualitas nutrisi pakan (Bidura, 2007). Jamur benang (filamentous fungi) seperti Trichoderma merupakan mikroorganisme yang banyak digunakan sebagai sumber probiotik untuk merombak polimer tanaman seperti selulose. Selain itu Trichoderma juga sangat efisien menggunakan nutrisi yang tersedia karena kemampuannnya memperoleh energi (ATP) dari metabolisme berbagai sumber karbohodrat seperti selulose, hemiselulose, xilan, mannan, arabinan, dan khitin (Delgado-Jarana et al., 2003). Trichoderma viridae (IMB-Tr) yang diisolasi dari jerami padi oleh Peiris dan Silva (1987) mampu menghasilkan enzim selulolitik dan silanolitik seperti yang dihasilkan oleh T. reesei. Trichoderma viridae (strain IMB-Tr) yang dibiakkan pada kultur media krital mikro selulase dan jerami padi mempunyai aktivitas glukosidase berturutturut 2,9 dan 1,9 kali lebih besar dibandingkan dengan T. reesei strain QM 9414. Substrat yang difermentasi dengan jamur tersebut dapat menghasilkan glukose, xilose dan selubiose.

Berdasarkan informasi tersebut perlu dilakukan serangkaian berbagai proses fermentasi dan bioproses lainnya terhadap bahan pakan jerami padi dengan menambahkan sumber nitrogen dari luar seperti urea (amoniasi), probiotik starbio dan komponen bioproses Trichoderma viridae untuk meningkatkan kualitas jerami padi. Dengan demikian, penelitian ini bertujuan untuk menemukan teknologi yang tepat dalam mengoptimalkan pemanfaatan jerami padi sebagai pakan dasar sapi Bali penggemukan.

\section{MATERI DAN METODE}

\section{Tempat dan Sapi}

Penelitian ini merupakan serangkaian percobaan di lapangan dan laboratorium yang menggunakan 12 ekor sapi bali jantan denga kisaran bobot 200-215 kg. Penelitian lapangan dilaksanakan di stasiun percobaan Dinas Peternakan milik Pemerintah Kabupaten Gianyar, Desa Siyut selama 5 bulan dengan persiapan penelitian 1 bulan, fermentasi selama 3 minggu, fase adaptasi pemberian pakan selama 1 minggu dan 3 bulan masa penelitian, sedangkan analisa laboratorium dilaksanakan di laboratorium Nutrisi Ternak Fakultas Peternakan UNUD Denpasar. 
Sapi percobaan dipelihara dalam kandang individu berukuran 2,25 $\mathrm{m} \times 1,0 \mathrm{~m}$ yang dilengkapi dengan tempat pakan dan air minum. Sapi percobaan tersebut ditempat secara acak sesuai dengan rancangan perbobaan yang digunakan.

\section{Pakan Penelitian}

Penelitian ini menggunakan jerami padi sebagai bahan pakan dasar sapi bali penggemukan. Adapun kandungan nutrisinya adalah $87 \%$ bahan kering (BK), protein kasar (PK) 4\%, total digestible nutrient (TDN) 51\%, serat kasar (SK) $33 \%$ dan abu (mineral) 25\%. Pemberian jerami padi baik tanpa perlakuan maupun dengan perlakuan amoniasi, biofermenetasi Starbio atau Trichoderma virideae dilakukan secara ad libitum yang waktunya diatur setelah pemberian pakan komersial (complete feed) sekitar pukul 10. o0 wita. Kandungan nutrien jerami padi dengan atau tanpa perlakuan dan kandungan nutrien complete feed dapat dilihat pada Tabel 1.

Tabel 1. Kandungan nutrien jerami padi dan complete feed

\begin{tabular}{lccccc}
\hline \multicolumn{1}{c}{ Nutrien } & $\begin{array}{c}\text { Jerami } \\
\text { Padi }\end{array}$ & $\begin{array}{c}\text { Jerami } \\
\text { Padi } \\
\text { Amoniasi } \\
\text { Urea }\end{array}$ & $\begin{array}{c}\text { Jerami } \\
\text { Padi } \\
\text { Terfermen-fermentasi } \\
\text { tasi } \\
\text { Starbio }\end{array}$ & $\begin{array}{c}\text { Jerami } \\
\text { Prichoder- } \\
\text { ma sp }\end{array}$ & $\begin{array}{c}\text { Complete } \\
\text { feed }\end{array}$ \\
\hline Bahan kering (\%) & 87,00 & 54,97 & 66,25 & 49,94 & 89,00 \\
Abu (\%) & 25,00 & 24,00 & 26,30 & 27,00 & 18,50 \\
Bahan organik (\%) & 81,50 & 75,90 & 73,50 & 72,70 & 81,63 \\
Protein kasar (\%) & 4,00 & 6,19 & 7,29 & 6,97 & 14,60 \\
Serat kasar (\%) & 33,00 & 33,61 & 30,72 & 29,15 & 5,65 \\
Total digestible & 51,00 & 60,78 & 58,79 & 58,38 & 64,00 \\
nutrient (\%) & & & & & \\
\hline
\end{tabular}

Keterangan: Analisis dilakukan di Laboratorium Nutrisi dan Makanan Ternak Fapet-Unud

Pakan lengkap (complete feed ) berfungsi sebagai konsentrat untuk memenuhi kebutuhan energi pada sapi percobaan. Pakan lengkap ini sebetulnya sudah cukup untuk memenuhi kebutuhan nutrien bagi sapi bali penggemukan. Berhubung harganya relatif mahal, maka pemberiannya cukup 155\% dari bobot hidup sapi.

\section{Fermentasi Jerami Padi}

Pembuatan jerami padi amoniasi urea adalah dengan pemberian urea (46\% nitrogen) sebanyak 4\% dari BK jerami padi yang sudah dipotong-potong sepanjang $8 \mathrm{~cm}$, dengan perbandingan 1:1 (air:BK jerami padi), dan selanjutnya larutan urea dan jerami padi diaduk merata, kemudian diperam selama 21 hari. Setelah 21 hari, jerami padi dibuka dan diangin-anginkan selama 1 hari sebelum diberikan pada ternak.

Bahan yang digunakan dalam biofermentasi jerami padi dengan Starbio adalah campuran $0,6 \%$ starbio dan urea sebanyak 0,06\% kemudian ditambahkan air secukupnya. Larutan Starbio ini dicampur dengan jerami yang telah dicincang dengan ukuran $8 \mathrm{~cm}$, kemudian peram selama 21 hari. Setelah 21 hari, pemanfaatannya sama dengan jerami padi amoniasi urea.

Biofermentasi jerami padi dengan Trichoderma virideae adalah dengan cara mengaktifkan Trichoderma virideae terlebih dahulu. Satu liter Trichoderma virideae+gula pasir $0,5 \mathrm{~kg}+1 \mathrm{~kg}$ Urea+1 $\mathrm{kg} \mathrm{NPK}+$ air 100 liter diaduk setiap 2 jam. Buih yang muncul dihilangkan dan didiamkan selama 24 jam. Setelah itu, Trichoderma virideae aktif dapat dipakai sebagai bahan fermentasi untuk 1 ton jerami padi dengan lama waktu fermentasi 14 hari. Setelah hari ke 14, jerami padi dibuka dan diangin-anginkan selama 1 hari sebelum diberikan pada ternak.

\section{Rancangan Penelitian}

Rancangan percobaan yang digunakan adalah rancangan acak kelompok dengan empat perlakuan dan tiga kelompok sebagai ulangan. Pengelompokan dilakukan berdasarkan perbedaan bobot awal ternak. Adapun perlakuan yang dicobakan terdiri atas: A $=$ jerami padi tanpa perlakuan+complete feed $1,5 \%$ dari bobot sapi (kontrol); $\mathrm{B}=$ jerami padi amoniasi urea+complete feed $1,5 \%$ dari bobot sapi; $\mathrm{C}=$ jerami padi fermentasi Starbio+complete feed $1,5 \%$ dari bobot sapi; D = jerami padi fermentasi Trichoderma virideae+complete feed $1,5 \%$ dari bobot sapi.

\section{Variabel yang Diamati}

Peubah yang diamati meliputi: konsumsi bahan kering, konsumsi protein, konsumsi energi, deposisi nutrien (lemak dan protein), retensi energi, pertambahan bobot harian, dan FCR (feed conversion ratio). Deposisi nutrien dapat diketahui dari konversi pertambahan bobot harian ternak ke dalam komposisi tubuh. Komposisi tubuh diukur dengan teknik ruang urea menurut Rule et al. (1986). Retensi energi dapat dihitung dengan konversi deposisi lemak dan protein, yaitu deposisi $1 \mathrm{~g}$ protein mengandung energi $5.5 \mathrm{kkal}$ dan $1 \mathrm{~g}$ lemak = $9.32 \mathrm{kkal}$ ( $\varnothing$ rskov dan Ryle, 1990). FCR dihitung dengan membagi konsumsi bahan kering dengan pertambahan bobot harian. Bobot hidup sapi diukur setiap 2 minggu sekali, dan pertambahan bobot hidup harian dapat diketahui dengan menghitung selisih antara bobot akhir dan awal dibagi dengan lama percobaan.

\section{Analisis Statistik}

Data yang diperoleh dianalisis dengan sidik ragam, dan bila perlakuan berpengaruh nyata dilanjutkan dengan Uji Kontras Ortogonal. 


\section{HASIL DAN PEMBAHASAN}

Perlakuan amoniasi urea dan biofermentasi dengan Starbio dan Trichoderma virideae pada jerami padi sebagai pakan dasar sapi bali penggemukan berpengaruh nyata $(\mathrm{P}<0,05)$ terhadap konsumsi bahan kering (BK) pakan (Tabel 2). Konsumsi BK pakan pada sapi yang diberi jerami padi dengan perlakuan biofermentasi Starbio (C) atau Trichoderma virideae (D) nyata $(\mathrm{P}<0,05)$ lebih rendah daripada sapi yang diberi perlakuan kontrol (A) atau jerami padi dengan amoniasi urea (B), yaitu 6,8 dan 6,6 vs $7,1 \mathrm{~kg} /$ ekor/ hari. Penurunan konsumsi bahan kering ini disebabkan oleh kecukupan energi yang dipasok pada perlakuan biofermentasi yang ditandai lebih tingginya kandungan total digestible nutrient (TDN) pada jerami padi dengan perlakuan Starbio dan Trichoderma virideae dibandingkan dengan jerami padi tanpa perlakuan seperti nampak pada Tabel 1 (58.79 dan 58.38 vs 51\%). Hal ini sesuai dengan penelitian Partama (2000) bahwa ransum dengan kadar energi lebih tinggi dikonsumsi lebih rendah daripada ransum yang berenergi lebih rendah pada ternak ruminansia. Bila dicermati lebih jauh, nampak bahwa konsumsi BK pada perlakuan kontrol adalah sama dengan konsumsi pada sapi yang diberi jerami dengan amoniasi urea, namun energi yang dipasok lebih tinggi pada perlakuan amoniasi seperti tersaji pada Tabel 2 (163 vs $211 \mathrm{kkal} / \mathrm{kgW}^{0.75}$ ). Lebih tingginya pasokan energi pada sapi yang diberi jerami amoniasi urea disebabkan kadar TDN (\%) lebih tinggi dibandingkana dengan jerami padi tanpa perlakuan (60,78 vs 51\%). Fenomena ini menunjukkan bahwa konsumsi pakan pada ternak bertujuan untuk memenuhi kebutuhan energi yang digunakan untuk hidup pokok dan berproduksi.

Tabel 2. Pengaruh perlakuan amoniasi dan biofermentasi pada jerami padi terhadap konsumsi ransum, deposisi nutrien dan pertambahan bobot hidup sapi bali penggemukan

\begin{tabular}{|c|c|c|c|c|}
\hline \multirow[b]{2}{*}{ Peubah } & \multicolumn{4}{|c|}{ Perlakuan $^{* *}$} \\
\hline & Jerami Padi & $\begin{array}{c}\text { Jerami Pad } \\
\text { Amoniasi } \\
\text { Urea }\end{array}$ & $\begin{array}{l}\text { JiJerami Padi } \\
\text { Terfermen- } \\
\text { tasi Starbio }\end{array}$ & $\begin{array}{l}\text { Jerami Padi } \\
\text { Terfermen- } \\
\text { tasi Tricho- } \\
\text { derma }\end{array}$ \\
\hline \multicolumn{5}{|l|}{ Konsumsi: } \\
\hline - Bahan kering $(\mathrm{kg} / \mathrm{e} / \mathrm{h})$ & $7,1 \pm 0,3^{b^{*}}$ & $7,1 \pm 0,1^{b}$ & $6,8 \pm 0,3^{a}$ & $6,6 \pm 0,2^{a}$ \\
\hline - Protein kasar (g/e/h) & $557 \pm 7,0^{a}$ & $653 \pm 6,7^{d}$ & $627 \pm 6,1^{c}$ & $595 \pm 9,0^{b}$ \\
\hline - Energi (kkal/kgW0.75/h) & $163 \pm 4,0^{\mathrm{a}}$ & $211 \pm 6,7^{c}$ & $192 \pm 7,0^{b}$ & $183 \pm 6,1^{b}$ \\
\hline \multicolumn{5}{|l|}{ Deposisi: } \\
\hline - Protein (g/e/h) & $57 \pm 7,0^{a}$ & $74 \pm 5,0^{c}$ & $67 \pm 3,0^{b}$ & $64 \pm 4,0^{b}$ \\
\hline - Lemak (g/e/h) & $132 \pm 7,0^{\mathrm{a}}$ & $174 \pm 5,0^{c}$ & $156 \pm 9,0^{b}$ & $149 \pm 8,0^{b}$ \\
\hline Retensi energi (Mkal/e/h) & \multicolumn{4}{|c|}{$1,54 \pm 0,10^{\mathrm{a}} 2,03 \pm 0,18^{\mathrm{c}} 1,82 \pm 0,16^{\mathrm{b}} 1,74 \pm 0,12^{\mathrm{b}}$} \\
\hline Pertambahan bobot $(\mathrm{kg} / \mathrm{e} / \mathrm{h})$ & \multicolumn{4}{|c|}{$0,41 \pm 0,05^{a} 0,53 \pm 0,03^{c} 0,47 \pm 0,02^{b} 0,46 \pm 0,02^{b}$} \\
\hline Feed conversion ratio (FCR) & $17,3 \pm 2,0^{c}$ & $13,4 \pm 1,9^{a}$ & $14,5 \pm 1,0^{b}$ & $14,3 \pm 2,05^{b}$ \\
\hline
\end{tabular}

Konsumsi protein kasar menunjukkan perbedaan yang nyata $(\mathrm{P}<0,05)$ pada sapi yang mendapat perlakuan pakan berbeda (Tabel 2). Rataan konsumsi protein kasar berkisar 557-653 g/ekor/hari, dan konsumsi tertinggi pada sapi yang mendapat perlakuan jerami padi amoniasi urea (653 g/ekor/hari setara dengan 11 $\mathrm{g} / \mathrm{kgW}^{0.75}$ per hari). Hasil penelitian ini lebih tinggi daripada laporan Partama et al. (2003) yang mencoba ransum komplit berbasil jerami padi amoniasi urea pada sapi bali penggemukan, yaitu 11 vs $8.6 \mathrm{~g} / \mathrm{kgW}^{0.75}$. Lebih tingginya pasokan protein pada penelitian ini tidak diikuti oleh pertabahan bobot sapi yang lebih tinggi dibandingkan dengan penelitian Partama et al. (2003), yaitu 0,53 vs $0,9 \mathrm{~kg} /$ ekor/hari. Hal ini membuktikan bahwa kadar energi ransum lebih berperan daripada kadar protein dalam mempengaruhi pertambahan bobot hidup ternak penggemukan, asal tidak terjadi defisiensi protein. Kadar energi ransum pada penelitian terdahulu lebih tinggi daripada penelitian ini, yaitu 67 vs $62 \%$ TDN.

Suplementasi konsentrat dalam pakan berbasis jerami dilakukan dengan maksud untuk menyediakan bahan pembentuk protein mikroba, seperti amonia $\left(\mathrm{NH}_{3}\right)$, asam lemak volatile (VFA) yang cukup pada rumen, sehingga pertumbuhan mikroba rumen menjadi cepat (Kim et al., 2018). Pesatnya pertumbuhan mikroba rumen akan meningkatkan populasi dan aktivitas dalam mencerna serat kasar.

Perlakuan amoniasi dan biofermentasi mikroba pada jerami padi berpengaruh nyata $(\mathrm{P}<0,05)$ terhadap konsumsi energi pada sapi bali penggemukan. Konsumsi energi tertinggi pada sapi yang mendapat perlakuan jerami padi amoniasi urea, yaitu $211 \mathrm{kkal} / \mathrm{kgW}^{0.75} / \mathrm{hari}$. Hasil ini nyata lebih tinggi daripada sapi yang mendapat perlakuan yang lain. Lebih tingginya konsumsi energi ini disebabkan oleh lebih tingginya kadar TDN (\%) pada jerami padi amoniasi urea dibandingkan dengan jermi padi yang lain (Tabel 1). Hasil penelitian ini lebih rendah dibandingkan dengan hasil penelitian Partama et al. (2003), yaitu 211 vs $271 \mathrm{kkal}^{\mathrm{kgW}} \mathrm{K}^{0.75}$. Hal ini dapat dipahami karena pasokan energi yang lebih tinggi diikuti oleh pertambahan bobot yang lebih tinggi yang mencapai hampir 2 kali lipat hasil penelitian ini (o.53 vs $0.9 \mathrm{~kg} / \mathrm{ekor} / \mathrm{hari})$.

Pakan perlakuan berpengaruh nyata $(\mathrm{P}<0,05)$ terhadap deposisi protein dan deposisi lemak pada sapi bali penggemukan (Tabel 2). Deposisi protein berkisar 57-74 g/ekor/hari, sedangkan deposisi lemak berkisar 132-174 g/ekor/hari. Deposisi nutrien tertinggi, baik protein maupun lemak terdapat pada sapi yang diberi pakan jerami padi amoniasi urea. Hal ini sejalan dengan pasokan energi paling tinggi pada sapi yang diberi jerami padi amoniasi urea, yaitu 211 $\mathrm{kkal} / \mathrm{kgW}^{0.75}$ per hari. Retensi energi mencerminkan 
tingkat pemanfaatan energi untuk produksi yang direpresentasikan dengan pertambahan bobot hidup sapi. Makin tinggi retensi energi, maka makin tinggi produksi ternak tersebut (Partama, 2017; Siti et al., 2013). Hasil penelitian ini menunjukkan bahwa sapi yang diberi jerami padi dengan perlakuan amoniasi urea (perlakuan B) menghasilkan retensi energi paling tinggi yaitu 2,03 Mkal/ekor/hari setara dengan 34,35 $\mathrm{kkal} / \mathrm{kgW}^{0.75} / \mathrm{hari}$. Hasil ini nyata $(\mathrm{P}<0,05)$ lebih tinggi daripada perlakuan jerami yang lain (Tabel 2). Namun demikan, hasil penelitian ini jauh lebih rendah dibandingkan dengan penelitian terdahulu (Partama et al., 2003), yaitu 34,35 vs $61,00 \mathrm{kkal} / \mathrm{kgW}^{0.75} /$ hari. Tillman et al. (1991) melaporkan bahwa retensi energi untuk pertambahan bobot hidup sapi kastrasi berbobot $300 \mathrm{~kg}$ berkisar $18.4 \%$ dari konsumsi energi, sedangkan Partama et al. (2003) mendapatkan 16,51\% dari konsumsi energi. Hasil penelitian ini hampir sama dengan penemuan Partama et al. (2003), yaitu 16.30\% dari konsumsi energi. Perbedaan ini disebabkan adanya perbedaan jenis atau genetik dan bobot atau umur ternak. Secara umum sapi luar negeri lebih efisien memanfaatkan energi daripada sapi lokal.

Pertambahan bobot hidup sapi dan efisiensi pemanfaatan pakan yang direpresentasikan dengan nilai FCR (feed conversion ratio) juga dipengaruhi secara nyata $(\mathrm{P}<0,05)$ oleh pakan perlakuan (Tabel 2). Pasokan energi dengan efisiensi pemanfaatannya yang tinggi berpengaruh pada meningkatnya deposisi nutrien dan pada akhirnya menghasilkan pertambahan bobot hidup yang relatif lebih tinggi pada sapi dengan pakan dasar jerami padi amoniasi urea dibandingkan dengan perlakuan yang lain. Hal ini membuktikan bahwa sapi yang diberi complete feed sebanyak 1,5\% dari bobot hidup (setara dengan $3 \mathrm{~kg}$ BK complete feed) dan sisanya $3,1 \mathrm{~kg}$ BK jerami padi amoniasi urea menunjukkan pemanfaatan jerami padi secara optimal karena nyata $(\mathrm{P}<0.05)$ memberikan retensi energi tertinggi yaitu 2,03 $\mathrm{Mkal} /$ hari, serta efisiensi pemanfaatn pakan paling tinggi yang ditandai dengan nilai FCR paling rendah, yaitu 13,4 vs $14,3,14,5$, dan 17,3. Sebagai akibatnya pertambahan bobot hidup sapi nyata lebih tinggi daripada perlakuan yang lain (o.53 vs $0.47,0.46$, dan $0.41 \mathrm{~kg} / \mathrm{ekor} / \mathrm{hr}$ ). Hasil penelitian ini didukung oleh Widiani et al. (2020) yang melaporkan bahwa suplementasi $1,5 \mathrm{~kg}$ konsentrat pada ransum sapi berbasis rumput lapangan nyata dapat meningkatkan pertambahan berat badan dan efisiensi penggunaan pakan.

Konsentratnya adalah makanan yang kaya nutrisi dan mudah dicerna. Seperti dilansir Partama (2017) bahwa konsentrat akan mempercepat pertambahan berat badan ternak dan meningkatkan efisiensi pakan dengan lebih baik. Salah satu optimasi untuk mendapatkan efisiensi pemanfaatan pakan yang lebih baik adalah menentukan jumlah konsentrat yang tepat. Proses fermentasi dan amoniasi pada pakan akan dapat meningkatkan nilai nutrisi dan kecernaan pakan tersebut, sehingga akan berdampak pada efisiensi penggunaan pakan (Bidura et al., 2008). Hal senada dilaporkan oleh Kesuma et al. (2019b) bahwa efisiensi pakan sangat dipengaruhi oleh kualitas atau kandungan nutrisi dari pakan, serta kemampuan sapi untuk menggunakan nutrisi dalam pakan untuk pertumbuhan tubuh. Nilai FCR rata-rata diperoleh dari perbandingan jumlah pakan yang dikonsumsi dengan pertambahan bobot badan sapi. Semakin tinggi nilai FCR, semakin rendah efektivitas pakan untuk menghasilkan pertambahan berat badan ternak. Konversi ratarata biaya pakan menjadi pertambahan bobot badan adalah ukuran ekonomis dari biaya pakan yang harus dikeluarkan untuk menghasilkan pertambahan bobot.

Pada Gambar 1 nampak perubahan bobot hidup sapi yang diukur setiap 2 minggu menunjukkan secara konsisten bobt hidup sapi yang diberi pakan berbasis jerami amoniasi urea tetap paling tinggi dibandingkan dengan sapi yang diberi perlakuan lainnya.

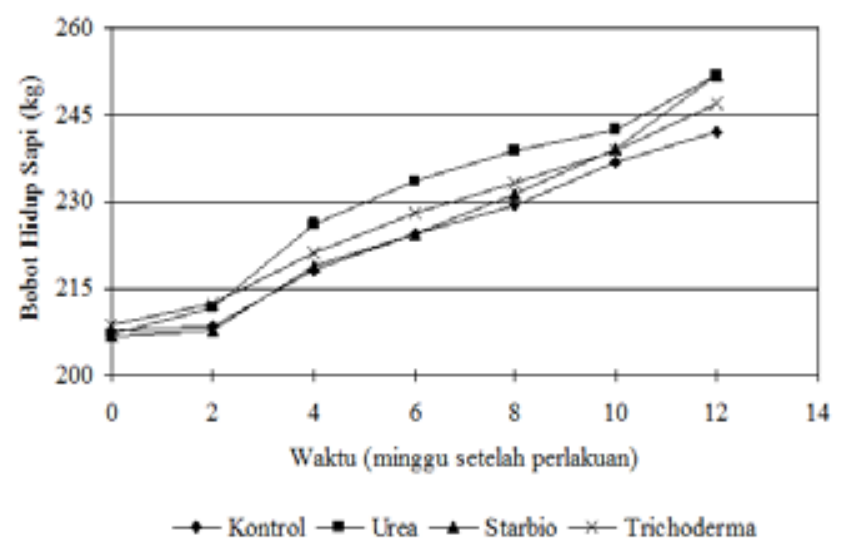

Gambar 1. Perubahan bobot hidup sapi pada keempat perlakuan pakan berbasis jerami padi

Meningkatkan sintesis protein mikroba dalam rumen penggemukan sapi adalah penting, karena memberikan kontribusi besar terhadap peningkatan produktivitas ternak. Menurut Mullik (2006), sekitar 60-80\% dari total protein yang dibutuhkan sapi berasal dari protein mikroba rumen. Disisi lain, potensi maksimum mikroba rumen untuk menghasilkan protein mikroba dan nutrisi terdegradasi dalam rumen dapat dieksplorasi hanya dengan menyediakan pakan berkualitas tinggi, yaitu konsentrat (Verbic, 2002) atau produk pakan hijauan yang diamoniasi (Bidura, 2007). Konsumsi hijauan yang meningkat, menyebabkan waktu hijauan di dalam rumen akan lama, sehingga dapat meningkatan penyerapan atau degradasi mikroba dalam rumen (Kim 
et al., 2018). Russell dan Wilson (1996) menjelaskan bahwa konsekuensi utama, jika $\mathrm{pH}$ rumen lebih rendah dari 6, akan terjadi degradasi serat kasar. Ini bisa terjadi karena dua alasan, yaitu enzim yang dibutuhkan untuk pemecahan serat kasar tidak berfungsi secara efektif pada $\mathrm{pH}<6,0$ dan laju pertumbuhan aktivitas bakteri fibrolitik menurun secara nyata pada $\mathrm{pH}$ rendah.

Lebih baiknya kinerja sapi yang diberi pakan berbasis jerami padi amoniasi urea, disebabkan oleh peranan urea yang mampu meningkatkan kecernaan jerami padi. Pada kondisi cukup air dan temperatur yang sesuai, urea yang ditambahkan pada jerami padi akan dihidrolisa oleh enzim urease yang dihasilkan oleh mikroorganisme pada jerami padi, membentuk senyawa amonium seperti amonium karbonat, amonium bikarbonat dan amonium hidroksida (Bidura et al., 2008). Amonium hidroksida menyusup kedalam serat jerami padi yang dapat melemahkan ikatan antara lignin dengan selulosa dan hemiselulosa sehingga mempermudah kerja enzim selulase dan hemiselulase yang dihasilkan oleh mikroba rumen yang pada akhirnya meningkatkan kecernaan jerami padi tersebut. Disamping itu adanya urea yang ditambahkan pada jerami padi dapat berfungsi sebagai sumber nitrogen $(\mathrm{N})$ dalam sistensis protein mikroba rumen sehingga sangat membantu perkembangan populasi dan aktivitas mikroba. Tingginya populasi mikroba ini sangat mendukung pertumbuhan hewan inang. Peningkatan pemanfaatan protein mikroba oleh ternak ditunjukkan oleh peningkatan sekresi allantoin dalam urin. Allantoin adalah derivat asam nukleat yang sebagian besar berasal dari mikroba rumen (Preston, 1995). Hal ini didukung oleh hasil penelitian Partama (2000) bahwa semakin tinggi produksi allantoin dalam urin semakin tinggi pertumbuhan ternak ruminansia.

Biofermentasi jerami padi dengan mikroba (Starbio dan Trichoderma virideae) belum mampu menyamai peubah respons yang ditampilkan oleh sapi bali penggemukan dengan pakan berbasis jerami padi amoniasi urea. Starbio lebih berperan sebagai pemasok nutrien di dalam pakan ternak, disamping dapat mendukung keseimbangan mikroba di dalam saluran pencernaan (Parker, 1974). Walaupun Starbio mengandung sejumlah mikroba pencerna serat dan protein seperti lignolitik, sellulitik, dan proteolitik, kerjanya tidak efektif di luar tubuh ternak, dan lebih efektif bila bekerja dalam saluran pencernaan. Kondisi ini tidak mungkin menyamai perlakuan amoniasi pada jerami padi yang berkerja di luar tubuh ternak dan selanjutnya memudahkan kerja mikroba rumen mencerna serat setelah ikatan lignin dengan selulosa dan hemiselulosa dirontokkan oleh senyawa amonium. Hal yang sama juga ditunjukkan oleh perlakuan biofermentasi pada jerami padi dengan Trichoderma virideae. Jamur ini juga lebih berperan pada saluran pencernaan. Bila enzim-enzim yang dihasilkan tidak didukung atau tidak sesuai dengan kondisi seperti di saluran pencernaan, maka aktivitas enzim dalam mencerna substrat menjadi tidak optimal. Lingkungan di luar saluran pencernaan jelas berbeda dengan lingkungan di saluran pencernaan. Oleh karena itu kerja Trichoderma virideae pada jerami padi tidak seoptimal perlakuan amoniasi.

Pencernaan konsentrat atau produk pakan terfermentasi/teramoniasi lebih cepat daripada kecernaan jerami. Signifikansi linear dari total produksi gas menunjukkan hubungan proporsional langsung antara total produksi gas dan jumlah konsentrat yang disediakan (Kim et al., 2018). Pakan konsentrat atau pakan teramoniasi memiliki komponen dinding sel yang lebih rendah dari hijauan. Oleh karena itu, peningkatan pakan konsentrat telah diusulkan untuk mitigasi $\mathrm{CH}_{4}$. Namun, komposisi nutrisi yang berbeda akan menghasilkan produksi $\mathrm{CH}_{4}$ yang berbeda pula (Kim et al., 2013). Hal ini didukung oleh Cakra et al. (2014) yang melaporkan bahwa suplementasi 10\% konsentrat dalam 90\% hijauan secara signifikan meningkatkan kecernaan bahan kering, bahan organik, protein kasar, dan serat kasar.

Rata-rata pertambahan bobot badan harian sapi potong lokal di Indonesia hanya $0,37 \mathrm{~kg}$, sedangkan kondisi ideal adalah 0,8-0,9 $\mathrm{kg}$ (Soedjana et al., 2012). Karena produktivitas yang rendah, sapi lokal di Indonesia lebih sering disembelih ketika mereka mencapai $60-80 \%$ dari potensi genetik dan ekonomi mereka (Diwyanto dan Saptati, 2010). Secara genetik, menurut Diwyanto dan Priyanti (2008), berat akhir ideal sapi bali jantan dapat mencapai $300-400 \mathrm{~kg}$. Penampilan sapi bali (pertumbuhan, kualitas daging, produksi anak dan susu) dapat ditingkatkan dengan meningkatkan kualitas pakan yang diberikan (Mastika dan Puger, 2009). Produktivitas sapi potong selama periode penggemukan dipengaruhi oleh kualitas dan kuantitas pakan yang diberikan peternak. Ketika kecukupan pakan tertutup selama fase pertumbuhan, sintesis jaringan tubuh meningkat (Tahuk et al., 2018). Kondisi seperti itu berdampak positif pada pertambahan bobot badan dan produksi karkas sapi.

Efek nutrisi akan lebih besar jika pemeliharaan dimulai pada awal periode pertumbuhan. Jadi pertumbuhan dapat dimanipulasi oleh berbagai manajemen nutrisi (Partama, 2017). Rata-rata pertambahan berat badan harian pada sapi lokal menurut Soedjana et al. (2012) adalah 0,30-0,75 kg/hari untuk peranakan Ongole atau Ongole; $0,35^{-0}, 66 \mathrm{~kg} /$ hari untuk sapi bali; dan $0,25-0,60 \mathrm{~kg} /$ hari untuk sapi madura. Ini berarti bahwa pertambahan bobot badan harian sapi dalam penelitian masih sama dengan pertambahan bobot badan harian sapi lokal pada umumnya. Yogyantara 
et al. (2014) melaporkan bahwa peningkatan level konsentrat dalam ransum berbasis hijauan dapat meningkatkan komposisi tubuh dan 60\% level konsentrat dalam ransum menghasilkan komposisi tubuh yang optimal pada kambing persilangan etawah. Suplementasi konsentrat pada penggemukan sapi diharapkan dapat meningkatkan konsentrasi asam propionat dalam rumen, sehingga pertumbuhan sapi bisa optimal. Dilaporkan oleh Kim et al. (2018) bahwa konsentrasi propionat tertinggi ditemukan di rumen jika ternak diberi proporsi pakan konsentrat yang tinggi, sedangkan konsentrasi butirat tertinggi adalah dalam proporsi konsentrat sedang. Juga dilaporkan bahwa proporsi konsentrat yang tinggi menghasilkan gas total tertinggi dalam semua periode inkubasi, sedangkan konsentrasi metana $\left(\mathrm{CH}_{4}\right)$ tertinggi adalah pada proporsi konsentrasi terendah dan terendah dalam proporsi konsentrat sedang.

\section{SIMPULAN}

Hasil penelitian ini menyiimpulkan bahwa jerami padi yang diberi perlakuan amoniasi dan biofermentasi dengan mikroba (Starbio dan Trichoderma virideae) dapat meningkatkan fungsinya sebagai pakan dasar sapi Bali penggemukan yang ditandai dengan meningkatnya konsumsi dan deposisi nutrien, retensi energi, efisiensi pemanfaatan pakan dan meningkatnya pertabahan bobot hidup sapi.

\section{UCAPAN TERIMA KASIH}

Penulis mengucapkan terima kasih kepada Rektor Universitas Udayana dan Dekan Fakultas Peternakan Universitas Udayana atas ijin yang diberikan sehingga penelitian ini dapat berlansung sesuai rencana. Terima kasih juga diucapkan kepada Kepada Dinas Peternakan Pemkab Gianyar atas fasilitas kandang yang diberikan dan sarana prasarana lainnya, sehingga penelitian dapat berlangsung dengan baik. Kepada Widyawati, dan A.A.N. Kusuma Yuda atas bantuannya mengkoleksi data di lapangan, sehingga penelitian ini dapat diselesaikan sesuai rencana.

\section{DAFTAR PUSTAKA}

Badan Pusat Statistik Provinsi Bali. 2018. Bali dalam Angka. BPS Propinsi Bali, Denpasar.

Bidura, I.G.N.G. 2007. Aplikasi Produk Bioteknologi Pakan Ternak. Udayana University Press, Denpasar.

Bidura, I G.N.G, T.G.O. Susila dan I. B. G. Partama. 2008. Limbah, Pakan Ternak Alternatif dan Aplikasi Teknologi. Udayana University Press, Denpasar.

Cakra, I G. L. O., Duarsa, M. A. P. dan Putra, S. 2014.
Digestibility Of Dry Matter And Nutrient Content Of Etawah Cross Bred Fed With Forage In Different Molamik Concentrate. Majalah Ilmiah Peternakan Vol. 17 (1): 10-14

Delgado-Jarana, J., M. Á. Moreno-Mateos, and T. Benítez. 2003. Glucose Uptake in Trichoderma harzianum: Role of gtt1. Eukaryotic Cell, August 2003, p. 708717, Vol. 2, No. 4 http://www.calricestraw.org/library/ abstracts/energy0074.html

Diwyanto, K. dan A. Priyanti. 2008. Kondisi, Potensi dan Permasalahan Agribisnis Peternakan Ruminansia dalam mendukung ketahanan pangan. Prosiding Seminar Nasional. Penerbit BP UNDIP, Semarang 3 Agustus 2006: 155-167

Diwyanto, K. dan R.A. Saptati. 2010. Tantangan dan peluang dalam mewujudkan ketahanan pangan asal ternak: susu dan daging sapi. dalam: Menuju kedaulatan pangan. Dit. Jen Dikti-Kemendiknas.

Kim, S-H, Lovelia L. Mamuad, Eun-Joong Kim, Ha-Guyn Sung, Gui-Seck Bae, Kwang-Keun Cho, Chanhee Lee \& Sang-Suk Lee.2018. Effect of different concentrate diet levels on rumen fluid inoculum used for determination of in vitro rumen fermentation, methane concentration, and methanogen abundance and diversity, Italian Journal of Animal Science, 17:2, 359-367, DOI: 10.1080/1828051X.2017.1394170

Kim, S. H, Mamua, L. L, Jeong C. D., Choi Y. J., Lee S. S., Ko J. Y., Lee S. S. 2013. In vitro evaluation of different feeds for their potential to generate methane and change methanogen diversity. Asian-Aust J Anim Sci. 26: 1698-1707.

Kusuma, I K. N., I. B. G Pertama, I G. N. G. Bidura, dan I K. Puja 2019a. Profile of inseminators and insemination practices in Bali, Indonesia. Research Journal of Veterinary Practitioners Vol. 7 (3): 63-66.

Kesuma, I K. G. N., I K. Puja, I. B. G. Partama and I G. N. G. Bidura. 2019b. Analysis of Some Factors that Affect the Success of the Implementation of Special Programs For Pregnance Cows ("UPSUS SIWAB") in Bali Province, Indonesia. J. Biol. Chem. Research. Vol. 36 (2): 69-79

Mastika, I M. dan A.W. Puger, 2009. Sapi Bali (Bos Sondaicus) permasalahan dan kenyataannya, dalam pengembangan sapi Bali berkelanjutan dalam sistem peternakan rakyat (Seminar Nasional), 28 Oktober 2009 di Mataram, Indonesia

Mullik, M. L. 2006. Strategi suplementasi untuk meningkatkan efisiensi sintesis protein mikroba rumen pada ternak sapi yang mengkonsumsi rumput kering tropis. Jurnal Ilmu Ternak dan Veteriner (JITV). 11(1):15-23.

Parker, R. B. 1974. Probiotics the other half of the antibiotic story. Anim. Nutr. Health. 29:4-8.

Partama, I. B. G. 2000. Kebutuhan Energi dan Protein 
Kambing Peanakan Etawah Calon Pejantan. Disertasi Program Doktor PPs. IPB, Bogor.

Partama, I. B. G. 2017. Nutrisi dan Pakan Ternak Ruminansia. Udayana University Press, Denpasar-Bali, Indonesia.

Partama, I. B. G., T. G. O. Susila, I W. Suarna dan I M. Suasta. 2003. Peningkatan Produktivitas Sapi Bali Kereman melalui Suplementasi Mineral dalam Ransum Berbentuk Wafer yang Berbasis Jerami Padi Amoniasi Urea. Laporan Penelitian Proyek Pengkajian Teknologi Partisipatif, BPTP-Bali.

Preston, T. R. 1995. Tropical Animal Feeding: A Manual for Research Workers. Animal Production and Health Paper No.126, FAO, Rome, Italy.

$\varnothing$ rskov, E.R., and M. Ryle. 1990. Energy Nutrition in Ruminants. Elseiver Applied Science. London.

Rule, D. C., R. N. Arnold, E. J. Hentgs, and D. C. Beitsz. 1986. Evaluation of urea dilution as a technique for estimating body composition of beef steers in vivo olidation of published equations and comparison with chemicl composition. J. Anim. Sci. 63: 1935 $-1948$.

Russell, J. B, and D. B. Wilson 1996. Why are ruminal cellulolytic bacteria unable to digest cellulose at low pH? J Dairy Sci. 79:1503-1509.

Siti, N. W., N. M Witariadi, N. K Mardewi, N. N. Candrasih K., I M Mudita, N. G. K. Roni I G. L. O Cakra, dan N. M. Suci Sukmawati. 2013. Nitrogen Utilization and Body Composition Of Etawah Crosbred Fed Forage Grass Field With Rice Bran Supplementation. Majalah Ilmiah Peternakan Vol. 16 (1): 18-22
Soedjana, TD., Bahri S., Diwyanto K., Priyanti A., Ilham N., Muharsini S., Tiesnamurti B. 2012. Menakar potensi penyediaan daging sapi dan kerbau di dalam negeri menuju swasembada 2014. Pusat Penelitian Dan Pengembangan Peternakan. Badan Penelitian dan Pengembangan Pertanian, Kementerian Pertanian. Jakarta.

Tahuk, P. K., S. P. S. Budhi, Panjono and E. Baliarti. 2018. Nitrogen balance, microbial protein synthesis and blood metabolites in fattening of male Bali cattle fed ration with different protein levels in smallholder farms. J. Indonesian Trop.Anim.Agric. 43 (1): 43-53

Tillman, A.D., H. Hartadi, S. Reksohadiprodjo. S. Prawirokusumo dan S. Labdosoekojo. 1998. Ilmu Makanan Ternak Dasar. Gadjah mada University Press.

Verbic, J. 2002. Factors affecting microbial protein synthesis in the rumen with emphasis on diets containing forages. Viehwirtschaftliche Fachtagung 29, 24-25 April. Bundesanstalt für alpenländische Landwirtschaft Gumpenstein, 8952 Irdning. Pp. 1-6.

Widiani, I. A. K., I G. N. G. Bidura, and B. R. T. Putri. 2020. Performance of Fattening Bali Cattle on Feedlot Systems which are Provided by Local Grass and Concentrate Supplementation. International Journal of Fauna and Biological Studies Vol. 6 (7): 7-13

Yogyantara A.P. I.K.D, I W. Suarna dan N. N. Suryani. 2014. Effect of Concentrate Levels in the Ration on Body Composition in Etawah crossbreed goats. Majalah Ilmiah Peternakan Vol. 17 (3): 113-116 